\title{
An Empirical Analysis of Cash Crop Production, Transport and the Nigerian Economy
}

\author{
Eravwoke Kester Erhieyovwe (Ph.D), Ukavwe Andrew \\ Department of Economics College of Physical Edu, Mosogar. Delta State \\ Department of Economics College of Education, Warri. Delta State
}

\begin{abstract}
The paper empirically examined cash crop production, transport and the Nigerian economy from 1981-2012. The main aim of this study is to determine the impact of cash crop production and transport on the Nigerian economy. This paper estimates the effect of cash crop production, transport and the Nigerian economy via vector error correction model framework, the co-integration test and the OLS techniques. The result shows a significant relationship between cash crop production, transport and the Nigerian economy. The study, therefore recommends that the federal government should increase its allocation to transport, to ensure adequate provision of transport facilities in terms of road signs, traffic light, street light etc.
\end{abstract}

Keywords: Cash crop, transport, government consumption, Nigerian economy.

\section{Introduction}

In spite of the predominance of petroleum sub-sector in Nigeria's economic growth and development, agricultural sector still remains a major source of economic resilience (Ojo and Akanji 1996).Agriculture contributes to employment generation, poverty reduction through increase in food production, foreign exchange earnings and source of industry' raw resources (CBN, 2002). In 2001, agricultural sector contributed about 41 per cent to the country's GDP. Despite this fit, the sector's export was negligible and represent about 0.2 per cent of the total exports in the country. The major cause of the decline in agricultural exports had been linked to increase in investment in the oil sector. This has resulted to large inflows of foreign exchange and the neglect of the agricultural sectors. Domestic food production declined substantially, causing food import bills to attain a height of about $\$ 4$ billion in 1982 and N98 trillion naira or $\$ 62.8$ billion between 2007 -2010 (CNB, 2011). In 2010 , alone, Nigeria spent N632 billion or (\$4.21b) on importation of wheat, N356 billion or ( $\$ 2.37 \mathrm{~b})$ on importation of rice, $\mathrm{N} 217$ billion or $(\$ 1.45 \mathrm{~b})$ on sugar importation and $\mathrm{N} 97$ billion or $(\$ 0.65 \mathrm{~b})$ on importation of fish (CBN, 2011).

The cash crop sub sector was the major area of government price intervention in the pre structural adjustment period (i.e., the period before 1986). The government replaced the Regional Marketing Boards, which controlled export cash crops prices from 1949 to 1976, with the National Commodity Board in 1977. Central machinery was evolved for the determination of producer prices of the crops. This measure was adopted in the belief that by improving commodity prices periodically, farmers' incomes and agricultural productivity would be enhanced (Akanji and Ukeje, 1995).Despite these incentives, it is observed that several agricultural policy programme implemented by the federal government of Nigeria accompany cash crop output variability (CBN, 2010). For example, the rate of cocoa output volatility decreased from $36.4 \%$ in the period 1971- 1976, fluctuating over the years to $4.20 \%$ in the period 1980-1985, then increased to $61.60 \%$ in 1986-1989 (Garba, 2000). Although, sustained growth is a rare achievement, especially in the sub Saharan Africa (Adedipe, 2004);Agénoret al., (2000) relates output volatility to policy inconsistency in developing countries. Essang (1973) and Muroi (1989) also correlate crop output volatility in Nigeria to poor policy on technology and land use Acts.

Agriculture contributes to employment, food production, foreign exchange earnings and industrial inputs. In 2001, agriculture was about 41 per cent of GDP. Some 60 per cent of the workforce is employed in agriculture, predominantly small holders (CBN, 2002). Nigeria has a total land area of 98.3 million hectares, of which only 71.2 million hectares are cultivable. Only 34.2 million hectares (about 48 per cent of the cultivable area) are actually being cultivated, and less than 1 per cent of the arable land is irrigated (FMARD, 2001). The modest growth of between 5.5 per cent and 7.5 per cent in the agricultural sector over the period 1999-2005 has been traced to the favourable weather conditions, while services and commerce expanded, following improvements in the purchasing power of consumers.

Back in the days, in Nigeria, cocoa was a major crop that sustained the western Nigerian government and it contributed a certain percentage of income to the federal purse. But the neglect of the agricultural subsector with its immense potential exemplified by the groundnut pyramids in the north, oil palm trees, rubber plantations in the Midwest, to mention just a few, whether as a result of policy ineffectiveness or errors of 
commission and omission, analysts have argued, is responsible in part for the parlous state of the once booming cocoa industry.

The account of Nigerian cocoa progression is a very fascinating story indeed. Regrettably, the over reliance on oil has inadvertently led to the dwindling fortunes of most Nigerian cocoa farmers, who have had to relinquish their position as Africa's leaders in the production of the cash-crop to Côte d'Ivoire position.

Cocoa and groundnuts were Nigeria's two major exports until petroleum surpassed both in 1965. Cocoa, cotton, groundnuts, oil palm products, and rubber were the principal export crops in the 1960s and early 1970s, but with export reorientation, only cocoa remained of any importance after 1975. Although Nigeria was the world's largest exporter of groundnuts in the early 1970s, groundnuts fell from the export list by the end of the 1970s as a result of the severe Sahel drought of 1972-74 and a viral disease in 1975. With assistance from the World Bank, the government restored cocoa production in the late 1970s and 1980s through replanting programs and producer price supports. The resulting increase in cocoa output (to 200,000 tons in 1988) kept Nigeria in third place among world cocoa producers, after Ivory Coast and Ghana.

Interestingly, cocoa came to be one of the symbols of commerce and industry and a stamp of legacy and honour bequeathed to the Southwest Nigeria by the pantheon of Yoruba politics, late Chief Obafemi Awolowo. As the Premier of the Old Western Region, revenues from cocoa formed parts of the funds deployed for the many landmark projects - infrastructural developments and funding of free education, among other many regional investments executed in the region by Awolowo. One of the famous relics is the Cocoa House in Ibadan, the Oyo State capital. The edifice, attests not only to the region's strong ties with cocoa farming but also represents one of the efficient avenues proceeds from the produce was well utilized and managed.

Before crude oil was discovered, agriculture was contributing immensely to the gross domestic product. In 1970, agriculture contributed 48 per cent to the GDP, but it dropped to 20.6 per cent in 1980 and had fallen to 23.3 per cent by 2005 . Crude oil's contribution to the GDP, on the other hand, rose from 29 per cent in 1980 to 59 per cent in 2005 . Hence, the emergence of petroleum has driven the unwavering devotion given to cocoa to the oblivion and eroded Nigeria's position as Africa's leader in production of the crop.

Africa produces about 70 per cent of the world's cocoa. Cote D'Ivoire is the leading cocoa producing nation with 1.3 million tones annually, while Ghana is rated second with about 900,000 tones. Nigeria produces only between $200,000-350,000$ tones annually. While the number of people who depend on cocoa worldwide for livelihood is estimated at 40-50 million, annual cocoa production is put at 3 million tones. The total number of cocoa farmers worldwide is calculated at over 6 million, comprising mostly Africans, Asians, Central Americans and South Americans. Africa is believed to have the greatest number of cocoa farmers but despite this plus, majority of its regular cocoa farmers still wallow in poverty due to poor standard of living, and various economic and environmental problems.

Agricultural output has been increasing at a slow rate over the last several years, except in 2002 and 2003, when the sector grew at an average rate of about 7.5 per cent per annum. The sector recorded moderate growth of 6.1 per cent and 6.5 per cent in 2004 and 2005 respectively. The growth of the staple crop production index has been oscillating between 3 and 3.6 per cent. All the major staples have recorded significant increases in output with the exception of maize. In spite of the decline in international market prices, cash crop production has been growing too, at least 3 per cent for cocoa, coffee and rubber between 1999 and 2004. The index of livestock production $(1984=100)$ has been rising by at least 2.4 per cent annually, while fisheries output has been rising by at least 3.6 per cent.

The paper is aimed at empirically investigating the influence of cash crop production, transport on the Nigerian economy.

\section{Literature Survey}

The studies on infrastructure, particularly, the efforts/ attempts to measure quantitative relationship between growth in transportation infrastructure and total economic growth using microeconomic model started with Antle (1983) when he estimated a Cobb Douglas production function for 47 developing countries and 19 developed countries. Infrastructure was specified as the gross national output from the transportation and communication industries per square kilometer of land area. Antle found a strong and positive relationship between the level of infrastructure and aggregate productivity. Mera (1973), Ratner (1983), Biehi (1986), Aschauer (1989), Binswanger et al (1987), Binswanger et al (1989), Easterly and Rebelo (1993), and Baffes and Shah (1993) also found transportation infrastructure as an effective factor of production. Thus, Aschauer (1989), investigated the role of infrastructure in development process based on the United States, he argued that nonmilitary public investment is far more important in increasing aggregate productivity than military spending. He concluded that core infrastructure such as street lights, highways, airports etc., contribute more to productivity than other forms of infrastructure, and that the slowdown of U.S productivity was related to the decrease in 
public infrastructure investment. Subsequently Munnell (1990), Garcia-milla and Guire (1992) found high elasticity of public infrastructure investment comparatively lower than Aschauers. Calderon (2009), provided a comprehensive assessment of the impact of infrastructure development on growth in African countries based on econometric estimates for a sample of 136 countries from 1960-2005. He evaluated the impact on per capita growth of faster accumulation of infrastructure stocks and enhancement in the quality of infrastructure services for 39 Africa countries in 3-key infrastructure sectors: telecommunications, electricity, and transportation (i.e road). Using an econometric technique suitable for dynamic panel models and likely endogenous regressors, the authors find that infrastructure stocks and services quality boost economic growth. The findings showed that growth is positively affected by the volume of infrastructure stocks and quality of infrastructure services Simulations show that our empirical findings are significant statistically and economically. Boopen (2006) analyzed the contribution of transport capital to growth for a sample of Sub Saharan African (SSA) and a sample of Small Island Developing States (SIDS), using both cross sectional and panel data analysis. In both cases, the analysis concluded that transport capital has been a contributor to the economic progress of these countries. Analysis further revealed that in SSA case, the productivity of transport capital stock is superior as compared to that of over all capital, unlike as in the SIDS, where transport capital is seen to have the average productivity level of over all capital stock.

\subsection{Agricultural Policy in Nigeria}

The last section identified some domestic agricultural policies among the various constraints preventing the realization of the potential of agricultural exports in Nigeria. This section explains the policy failures in greater detail.

Daramola (2004) argues that agricultural policy formulation in Nigeria is a typical market. This position is derived in part from Anderson and Tyers (1988), who argue that the forces of demand and supply for policies are conceptualized. In this view, policy beneficiaries demand policies and politicians supply them. Under the situation of 'distorted' pricing policy, as we have experienced in Nigeria in the recent past, the supply curve in this market represents the marginal political cost of providing an extra unit of protection to (or less taxation of) an industry, in terms of reduced political support from groups opposed to such a policy change, while the demand curve represents, at the margin, the preparedness of groups seeking policy change to offer various degrees of political support to the leadership. Under this general framework, there is also the need to accommodate social and government preferences, which include altruism, in addition to pressure from various private interest groups, on the supply side of policies. Therefore, the task has been reduced to examining the factors influencing the demand for and supply of distorted policies in Nigeria vis- $\cdot$ vis those of other countries at different stages of development. This is the foundation for the unfavourable agricultural policy environment prevailing hitherto in Nigeria.

In poor countries, the demand for agricultural protection, especially producer price support, is often weak. This is because marketable surplus and potential benefits are low relative to the high cost of collective action by farmers. It is costly to organize for collective action owing to the large numbers of farmers, geographical dispersion, poor infrastructure and low education in rural areas. Other pressure groups are not interested in policies favourable to agriculture because such groups - farm inputs and processing - are rudimentary. Urban elites favour industry, commerce, mining, construction and other sectors. In Nigeria, policies under successive military regimes before 1999 discouraged agriculture. The industrialists, being fewer in number, better educated, urban based, politically connected and with better access to infrastructure, gained better assistance and support policies. Generally, poor countries (including Nigeria) tax agricultural export and/or import in order to promote the manufacturing sector, which they expect to replace imports. Besides, it is easier to tax export commodities directly than to raise general tax revenue through income or sales tax because the latter option is rather expensive to collect.

\subsection{THE ROLE OF TRANSPORTATION IN NIGERIA}

2.2.1 Economic Role of Transportation: Economic activities are primarily concerned with the production, distribution and consumption of goods and services, which are of value to human. People must use the natural resources of the earth to satisfy the necessity of life, to provide food, clothing and shelter to the teeming population of the country. Not only for these basic necessities but also to use the resources to make life more pleasant, comfortable and rewarding. These resources are not usually found all in one place and no location is well endowed with all the resources. Thus, there is the universal need to transport some of these natural resource from places where they are abundantly available to areas where they are needed but not available. Most communities now consume food items produced in distance places because the cost of transportation is low. Such communities may exchanges these distant products with the ones they produce locally. For example foods that can be produced only in certain climates and soil condition are now available almost everywhere. As a result of reduced cost of transportation, there have been some substantial shifts in the location or points of 
extraction of raw material. For example the location of Kaduna Refinery in Nigeria, far away from the oil producing areas is economically attractive because of the cheapness of transportation. Example includes the movement of teachers to teach in certain areas and the travel of technicians to assist in solving problems within their fields in distant places. Increased mobility has economic implications. Land values increase as accessibility of the land increases. Transportation facilities help to keep price levels down. They permit stores in one area to compete with stores in areas not physically adjacent to it. The ability to increase the area of job search enables an individual to changes jobs as many times as he wishes. Employers also have a larger pool of potential employees. Were new facilities make the flow of persons and good more efficient pollution levels on other facilities from which traffic has been directed may decreased.

2.2.2 Political Role of Transportation: A minimal transportation system is a prerequisite for the rule of an area by a single government. To be able to govern an area, there should be a means by which messages would be passed on to the masses and vice versa. With the introduction of communication technology, it is much easier to send information through the media (radio, television, newspapers, fax, e-mail and website). Any form of representative government will depend on the transportation modes for the movement of the representatives from their constituencies to the seat of government and back. Transportation is particularly important if you have to send the police or troops to troubled areas from the central government in order to quell illegal activities or to defend the territorial integrity of your country against foreign invasion.

2.2.3 Environmental Role of Transportation: It has become necessary that many of humanity's productive activities, including transportation have serious effects on the natural environment. Apart from the use scarce resource, which is one of the effects of transportation on the environment, there are other environmental effects due to the provision of transportation. A convenient categorization of these effects consists of the following, (a) Pollution, (b) Consumption of energy, (c) Land use and loss of aesthetics and (d) Safety and accidents.

\subsection{Theoretical Models}

\section{Methodology and Data Sources}

The focus of our study is on the impact of cash crop production, transport on the Nigerian economy. Our analysis utilizes An analytical framework in the form of extended Cobb-Douglas production function, in which we are assuming a generalised Cobb-Douglas production and extending the Neo-classical growth model to include transport infrastructure stock (i.e output of the transport sector) along with cash crop production, investment on transport infrastructure as the input of the production function and the gross domestic product as the output. The model could be linearly stated as:

$\mathrm{LGDP}=\partial 0+\partial 1 \mathrm{CCP}+\partial 2 \mathrm{GFC}+\partial 3 \mathrm{TRP}+\mathrm{Ut}$

Where: GDP $=$ Proxy for growth of the Nigerian economy

$\mathrm{CCP}=$ Total cash crop

$\mathrm{GFC}=$ Government final consumption

TRP $=$ Transport

$\mathrm{L}=$ Natural logarithm

$\mathrm{Ut}=$ Random variable

\subsection{ANALYTICAL TECHNIQUES}

3.2.1 Vector Autoregressive Model

The VECM is used and the vector autoregressive were popularized by Sins (1980 as a natural generalization of univariable autoregressive models. A VAR is a systems regression model (i.e there is more than on dependent variable) that can be considered a kind of hybrid between the univariate time series models and the simultaneous equation models. An important feature of VAR model is its flexibility and ease of generalization. A useful facet of VAR model is the compactness with which the notation can be expressed. For example, $\mathrm{K}=1$, so each variable depends only upon the immediately previous values of $\mathrm{y}_{\mathrm{t}}$ and $\mathrm{y}_{2 \mathrm{t}}$, plus an error term (Brook, 2003).

The VAR model can estimate a vibrant simultaneous equation system without putting any prior restrictions on the structure of the relationships. Because it does not have any structural restrictions, the VAR system enables the estimation of a reduced form of correctly specified equations whose actual economic structure may be known.

VAR models have several advantages compared with univariate time series models or simultaneous equations structural models, for example a researcher does not need to specify which variable are endogenous or exogenous. All variables are endogenous. This is an important point, since a requirement for simultaneous equations structural models to be estimable is that all equations in the system are identified. Essentially, this 
requirement boils down to a condition that some variables are treated as exogenous and that the equations contain different right hand side variable. The vector error correlation model (VECM) is of the form:

$\mathrm{Dy}_{\mathrm{t}}=\delta \mathrm{B}^{1} \mathrm{y}_{\mathrm{t}}-1+\sum_{j=1}^{j=1} \quad \mathrm{Pj}_{j} \Delta y_{\mathrm{t}^{-}}{ }^{+} \mathrm{II}+\mathrm{C}_{\mathrm{t}} \mathrm{t}=1$

where $\mathrm{y}_{\mathrm{t}}$ is a vector of endogenous variable while the ${ }^{\propto}$ measures the speed of adjustment through which the

variables adjust to their long run values and the $\beta^{1}$ vectors are estimates of the long run cointegrating

relationships among variables in the model. It is the drift parameter and is the matrix of the parameters associated with the exogenous variables.

The study adopts the bounds testing cointegration procedure to estimate the long run and short run relationships and dynamic interaction among the variables of interest. Pesaran et al (2001) proposed an Autoregressive Distributed Lag (ARDL) bounds testing approach to investigating the existence of cointegration relationship among variables. There are three specific advantages associated with this approach:

(i) It circumvents the problem of the order of integration associated with the Johansen likelihood approach (Johansen and Juselius, 1990).

(ii) Unlike most of the conventional multivariate cointegration procedures, which are valid for large sample size, the bounds test approach is suitable for small sample size study (Pesaran et al, 2001).

(iii) It provides unbiased estimates of the long run model and valid t-statistics even when some of the regressors are endogenous (Harris and Sollis, 2003).

The Phillip and Perron (PP) and Augmented Dicky Fuller (ADF) tests. If a variable is found to be non stationery at levels, we proceed to test at first difference and so on when deciding whether to reject the null hypothesis of the unit root or not. The PP test is considered here because it accounts for possible correlation in the first differences of the time series using a non parametric correction, and allows for the presence of a non zero mean and a deterministic time trend. (Enders, 2010). Granger causality test and the short run analyses.

\subsection{Data Source}

Annual time series data are used in this study. The data are obtained from different sources, including various issues of the Central Bank of Nigeria Statistical Bulletins, International Financial Statistics, (IFS) Yearbooks published by the International Monetary Fund and National Bureau of Statistics.

\section{Result And Discussion}

The Angmented Dickey Fuller (ADF) and the Phillips - Perron (PP) unit root test and their order of integration is shown in table 1 below:

TABLE 1: SUMMARY OF ADF AND PP TEST RESULTS

ADF

PP

\begin{tabular}{|c|c|c|c|c|c|c|c|c|}
\hline Variables & ADF Levels & 1st Diff & 2nd Diff & Decision & Level & 1 st diff & $2^{\text {nd }}$ Dff & Decision \\
\hline $\mathrm{CCP}$ & -2.445526 & -9.448526 & & $1(1)$ & -2.728526 & -4.886881 & & $1(1)$ \\
\hline GFC & 3.386760 & & & $1(0)$ & 5.735083 & & & $1(0)$ \\
\hline TRP & 1.960766 & 2.283723 & -5.752348 & $1(2)$ & 1.816325 & -4.522024 & & $1(1)$ \\
\hline
\end{tabular}

Critical value $1 \%=-3.6852, \quad 5 \%=-2.9705, \quad 10 \%=-2.6242$

Source: Authors computation

The results of the ADF and PP test result indicates clearly that the null hypothesis (non-stationarity) is rejected as against the alternative, because the ADF and PP test statistics values are higher them the critical values at $1 \%$ level of significance. 
As can seen in the Augmented Dickey Fuller unit root test result cash crop production (CCP) and Transport are stationary at first difference i.e 1 (1) while Government final consumption is stationary at levels that is 1 (0). The result of the Philips and Perron (PP) test result equally reveals the same order of stationarity, this implies that there is a possibility of a long run relationship between the variables.

When all variables have attained the stationarity state we can call for long run relationship as can be seen in the $\mathrm{ADF}$ and PP test above. The co-integration test result indicates 3 co-integration equations at $5 \%$ significance level of significance. This confirms the existence of long run relationship among the variables.

Table 2: Summary of Johansen Co-Integrating Test

\begin{tabular}{|l|l|l|l|l|}
\hline Eigenvlue & likelihood & $\begin{array}{l}5 \text { Percent critical } \\
\text { value }\end{array}$ & $\begin{array}{l}1 \text { Percent critical } \\
\text { value }\end{array}$ & $\begin{array}{l}\text { Hypothesized No. of } \\
\text { CE(s) }\end{array}$ \\
\hline 0.963500 & 139.3776 & 47.21 & 54.46 & None ** \\
\hline 0.653510 & 46.68545 & 29.68 & 35.65 & At Most * $^{* *}$ \\
\hline 0.390659 & 17.00824 & 15.41 & 20.04 & At Most 2* \\
\hline 0.106009 & 3.137669 & 3.76 & 6.65 & At Most 3 \\
\hline
\end{tabular}

$*(* *)$ denotes rejection of the hypothesis at $5 \%(1 \%)$ significant level

LR test indicates 3 contegrating equation (s) at $5 \%$ significance level.

A comparism of the coefficients of the error term (Count Eq1) for the first vector shows that CCP and GFC has the most significant coefficient, with a t-value of 3.09834 and 4.33551 respectively and CCP has a correct negative sign. TRP is less significant. This suggests that cash crop production and government final consumption constitute the true co-integrating relationship in the first cointegrating vector.

Government final consumption has a positive long run relationship with growth ratio in the Nigerian economy as indicated by the significance of its coefficient. This means that an increase in Government final consumption will increase economic activities in Nigeria.

Table 4: Short Run Result

\begin{tabular}{|l|l|l|l|l|}
\hline Variable & Coefficient & Std. Error & T-statistic & Prob. \\
\hline Log (CCP) & 0.35797 & 0.020515 & 1.744884 & 0.0928 \\
\hline $\log ($ TRP) & 0.392568 & 0.069807 & 5.623661 & 0.0000 \\
\hline Log (GFC) & 0.101403 & 0.013833 & 7.330660 & 0.0000 \\
\hline C & 7.642824 & 0.463804 & 16.47855 & 0.0000 \\
\hline
\end{tabular}

$R$ squared 0.959076

Adjusted R-Squared 0.954354

F-statistic 203.1078

Durbin Watson 1.813875

Prob (F-statistic) 0.0000

From the regression result in table 4, the value of the constant term (intercept) is 7.642824. This signifies that if the explanation variable is held constant the GDP is 7.642824. The result suggested that a unit change in cash crop production (CCP) will cause a 0.035797 unit rise in Gross domestic product (GDP). A unit change in Transport (TRP) will equally cause a 0.3926568 rise in economic activities in the Nigerian economy, and lastly, a unit charge in government final consumption will cause a 0.101403 increase in economic activities in the Nigerian economy.

The coefficient of determination $\left(\mathrm{R}^{2}\right)$ is 0.959076 for the model, this indicates that there is a very strong positive linear relationship between dependent variable (GDP) and Explanatory Variables (CCP, TRP and GFC) and the explanatory variable accounted for 95 percent of the variation in GDP. While the remaining 5 percent variation in the GDP is explained by other exogenous variables that are excluded in the models (error term).

Also a brief look at the adjusted R-squared value of 95 percent indicate that after removing the effect insignificant repressor (explanatory variable) about 5\% variation in the GDP is still accounted for by the independent variables. Therefore, the model is of good fit.

The t-statistics suggested that CCP with a value of 1.744884 and probability of 0.0928 suggests that cash crop production in statistically significant in transforming economic growth of the Nigerian economy. The implication of this is that investment in cash crop production will result in rapid economic growth of the Nigerian economy.

Equally the t-test suggests that Transport with a value of 5.623661 and probability of 0.0000 is statistically significant in explaining economic growth in the Nigerian economy. The implication of this result is that the income the Nigerian government (i.e from federal government to state government and local government and even private sectors inclusive) spend in transportation is significant in transforming growth and development of 
the Nigerian economy. This finding is in agreement with the work of Akanbi .B, Bamidele .A and Auni .A (2013) who found out that transportation has a positive and statistically significant relationship with economic growth in Nigeria.

This implies that the federal government budget allocation to transport sector can transform economic activities in Nigeria.

\section{Conclusions and Recommendations}

The study analyses cash crop production, transport and the Nigeria economy the major cash crop considered were; Oil palm, Rubber, Cocoa, Cotton and Groundnut. The empirical result shows that investment in cash crop production will result in rapid economic growth of the Nigerian economy.

The study equally found that transportation has a positive and statistically significant relationship with economic growth in Nigeria. Following the result of the study we recommend that government should formulate appropriate specific cash crop policy packages as part of the holistic agricultural policy programme. This kind of policy programme in the country would ensure quick intervention and promote result oriented cash crop in the country. We equally recommend that the federal government allocation to transport sector should be increased because this will increase the funds directed to improve the available infrastructure and to add to the existing infrastructure.

In addition, the Federal Ministry of Transport should balance the federal government effort through transportation regulations, strict monitoring of implementation of the allocation, improving the quality of human resources and the involvement of the private sector. They should provide adequate transportation facilities in terms of road signs, traffic lights, street lights, medians, drainages, and functional mass transit vehicles by government and private individuals is necessary so as to minimize traffic congestion and accidents. Finally, the federal government of Nigeria should as a matter of policy promote long term planning in the agricultural sector and equally try to avoid ad hoc or short term policies especially in cash crop sub sector.

\section{Reference:}

[1]. Adeniji .K, (2000) Transport challenges in Nigeria in the next two decade. Key note address presented at the fifth national council of transport meeting organized by the federal Ministry of transport, Abuja.

[2]. Agenor, P. R., C. J. McDermott, and E. S. Prasad,(2000).“Macroeconomic fluctuations in Developing countries: Some stylized facts, "World Bank Economic Review, 14(2), 251-285.

[3]. Akanji, O.O. and E.U. Ukeje. (1995). "A review and analysis of agricultural prices in Nigeria" Economic and Financial Review, 33(1, March): 35-61.

[4]. Antle J.M, (1983) Infrastructure and Aggregate Agricultural Productivity: International Evidence. Economic Development and Cultural Change 31(1), 1983 (April): 609- 619.

[5]. Antle J.M, (1983) Infrastructure and Aggregate Agricultural Productivity:

[6]. Aschauer .D, (1989) 'Is Public Expenditure Productive?'. Journal of Monetary Economics, 23 (2), 1989, 177-200.

[7]. Baffes, J. and A. Shah. (1993) Productivity of Public Spending, Sectorial Allocation Choices and Economic Growth. Paper prepared for presentation at the 1993 Annual Meetings of American Economic Association, Anaheim, California.

[8]. Biehl .D, (1986) The Contribution of Infrastructure to Regional Development, European Communities, Luxembourg, 1986. http://catalogue.nla.gov.au/Record/577598

[9]. Boopen .S, (2006) Transport infrastructure and Economic Growth: Evidence from Africa Using Dynamic Panel Estimates. The Empirical Economic Letters, 5(1): ISSN 16818997.

[10]. Calderón .C, (2009) Infrastructure and Growth in Africa, Policy Research Working Paper 4914, The World Bank, Washington, D.C, 2009.

[11]. CBN, 2002, Annual Report and Statement of Account, Abuja: CBN.

[12]. CBN, 2005, Annual Report and Statement of Account, Abuja: CBN.

[13]. Central Bank of Nigeria: Statistical Bulletin Central Bank of Nigeria, 2002, 2010 and 2011. http/www.cbn.org/out/publications.

[14]. Easterly and Rebelo, (1993) Fiscal Policy and Economic Growth: An Empirical Investigation. Journal of Monetary Economics, .32 (3), 1993, 417-58.

[15]. Garba, P. K. (2000). An analysis of the implementation and stability of Nigerian agricultural policies, 1970-1993. AERC Research Paper 101African Economic Research Consortium, Nairobi

[16]. Garcia-Mila, and T. McGuire (1992) "The Contribution of Publicly Provided Inputs to States' Economies," Regional Science and Urban Economics, 22(2), 1992.

[17]. Mera .K, (1973) Regional Production Functions and Social Overhead Capital: An analysis of the Japanese Case, Regional and Urban Economics, 3(2), 1973 pp. 157-185.

[18]. Munnell, A.H. (1990) Why Has Productivity Declined? Productivity and Public Investment.ll New England Economic Review (Federal Reserve Bank of Boston), 1990, 3-22.

[19]. Nwakeze M.N, and A. Y. Mulikat (2010) Transportation and economic growth in Nigeria. Journal of research in national development 18(2), 2010.

[20]. Ojo M. O, Akanji F. (1996). Responsiveness of selected Agricultural Export Commodities to Exchange rate Devaluation in Nigeria. An Econometric analysis. CBN Economic and Financial Review, 34(2): $511-578$.

[21]. Pravakars, S., K. Ranjo, and N. Geethanjali. (2010). Infrastructure development and economic growth in China. IDE Disscussion paper No.261, pp1-16.

[22]. Ratner, J.B. (1983)" Government capital, Employment and the Production for US Private Output, Economic Letters, (13), 1983, 213-217. 